\title{
Simultaneous estimation of rosuvastatin and amlodipine in pharmaceutical formulations using stability indicating HPLC method
}

\author{
Muhammad Ashfaq ${ }^{1, *}$, Tazeem Akhtar ${ }^{1}$, Ghulam Mustafa ${ }^{1}$, Muhammad Danish ${ }^{1}$, Syed Naeem \\ Razzaq ${ }^{2}$, Muhammad Faizan Nazar ${ }^{1}$ \\ ${ }^{1}$ Department of Chemistry, University of Gujrat, Gujrat, Pakistan, ${ }^{2}$ Department of Chemistry, Government College University, \\ Lahore, Pakistan
}

\begin{abstract}
A viable cost-effective and isocratic approach employing C-18 column $(250 \mathrm{~mm} \times 4.6 \mathrm{~mm}, 5 \mu \mathrm{m})$ based HPLC has been utilized to separate and estimate the drugs, rosuvastatin, amlodipine and their stress induced degradation products, simultaneously in pharmaceutical formulations. Focused on ICH guideline parameters, the efficient separation of both drugs and their degradation products was achieved by optimizing a 30:70 (v/v) solvent mixture of acetonitrile and $0.1 \mathrm{M}$ ammonium acetate buffer $(\mathrm{pH} 5)$ as mobile phase. The flow rate of the mobile phase was $1.5 \mathrm{~mL} / \mathrm{min}$ and all the detections were carried out at $240 \mathrm{~nm}$ using UV detector. The method was linear in the concentration range of 1-200 $\mu \mathrm{g} / \mathrm{mL}$ for rosuvastatin with 0.996 coefficient of determination value. For amlodipine, linearity was in the range of $0.5-100 \mu \mathrm{g} / \mathrm{ml}$ with 0.994 coefficient of determination value. Both the drugs along with their degradation products were separated in less than twenty minutes. The results of within-day and between-day precision were varied from 0.72 to $1.81 \%$ for rosuvastatin and 0.83 to $1.88 \%$ for amlodipine. The results show that this ICH validated method can be employed successfully for the routine as well as stability quantification of both the active ingredients simultaneously in pharmaceutical formulations.
\end{abstract}

Uniterms: High Performance Liquid Chromatography/quantitative analysis. Rosuvastatin/quantitative determination. Amlodipine/quantitative determination. Pharmaceutical formulations/quantitative analyis. Acetonitrile. UV Detector.

Utilizou-se abordagem de viabilidade custo-efetividade e isocrática, baseada em CLAE, empregando coluna C-18 $(250 \mathrm{~mm} \times 4,6 \mathrm{~mm}, 5 \mu \mathrm{m})$ para separar e avaliar os fármacos, rosuvastatina, anlodipino e seus produtos de degradação induzida por estresse, simultaneamente, em formulações farmacêuticas. Focada nos parâmetros das diretrizes da ICH, a separação eficiente de ambos os fármacos e de seus produtos de degradação foi obtida por meio da otimização da fase móvel com mistura de solventes 30:70 (v/v), respectivamente, acetonitrila e tampão acetato de amônio $\mathrm{O}, 1 \mathrm{M}(\mathrm{pH}$ 5). A velocidade de fluxo da fase móvel foi de $1,5 \mathrm{~mL} / \mathrm{min}$ e todas as detecções foram realizadas em $240 \mathrm{~nm}$, utilizando detector de UV. O método foi linear no intervalo de concentração de $1-200 \mu \mathrm{g} / \mathrm{mL}$ para a rosuvastatina com coeficiente de determinação 0,996. Para o anlodipino, a linearidade ficou na faixa de 0.5-100 $\mu \mathrm{g} / \mathrm{mL}$, com coeficiente de determinação 0,994 . Ambos os fármacos, junto com seus produtos de degradação, foram separados em menos de vinte minutos. Os resultados de precisão intra-dia e inter-dia variaram de 0,72 a 1,81\% para a rosuvastatina e de 0,83 a $1,88 \%$, para o anlodipino. Os resultados mostram que este método validado pelo ICH pode ser empregado com sucesso tanto para a rotina quanto para a quantificação simultânea da estabilidade de ambos os ingredientes ativos em formulações farmacêuticas.

Unitermos: Cromatografia Líquida de Alto Desempenho/análise quantitative. Rosuvastatina/determinação quantitativa. Anlodipino/determinação quantitativa. Formulações farmacêuticas/análise quantitativa.

*Correspondence: M. Ashfaq. Department of Chemistry, University of Gujrat, H.H. Campus, Gujrat-50700, Pakistan. E-mail: ashfaqchemist@hotmail.com; ashfaqchemist@gmail.com 


\section{INTRODUCTION}

Rosuvastatin [Figure 1A] is the calcium salt of (E)-7-[4-(4-fluorophenyl)-6-isopropyl-2[methyl(methylsulfonyl)amino]pyrimidin-5-yl](3R,5S)3,5-dihydroxyhept-6-enoic acid. It is a competitive inhibitor of HMG-CoA reductase (Lennernas, Fager, 1997; Nissen et al., 2006), used in the treatment of dyslipidemia and hypercholesterolemia (McCormick et al., 2000; Olsson, McTaggart, Raza, 2002). Rosuvastatin is very effective in reducing low density lipoprotein cholesterol and many studies have demonstrated its superiority nature over other drugs of its class such as atorvastatin, simvastatin and pravastatin (Olsson et al., 2001; Paoletti et al., 2001; Davidson et al., 2002). Literature revealed many HPLC methods, including stability indicating methods, for the separation of rosuvastatin (Mehta et al., 2005; Pandya et al., 2010; Gomes et al., 2009; Kaila et al., 2010; Reddy et al., 2011; Mostafa et al., 2012; Trivedi, Patel, 2012).

Amlodipine besylate [Figure 1B], chemically designated as 2-[(2-aminoethoxy)-methyl]-4-(2chlorophenyl) 1,4-dihydro-6-methyl-3,5-pyridinedicarboxylic acid-3 ethyl-5 methyl ester, is a calcium channel blocker used to treat hypertension and angina (Arrowsmith et al., 1986; O` Neil et al., 2006). The drug is found to metabolize in the liver and the produced metabolites are excreted via urine along with some unchanged drug (Abernethy, 1989; Meredith, Elliott, 1992). Many stability indicating HPLC methods are reported in the literature for amlodipine either alone or in combination with other active pharmaceutical ingredients (Naidu, Kale, Shingare, 2005; Chaudhari, Patel, Shah, 2007; Mohammadi et al., 2007; Shah et al., 2008; Zaazaa et al., 2013; Gumustas, Ozkan, 2013).

The combination of antihyperlipidemic and antihypertensive agents is very proficient, as majority of hyperlipdemic patients may also have the hypertension problems. In order to cope with both the diseases simultaneously, a combination comprising of rosuvastatin and amlodipine was approved and marketed. This combination is available in the commercial market on prescription. Literature revealed only two HPLC methods for the simultaneous determination of both the drugs (Tajane et al., 2012; Banerjee, Vasava, 2013). The reported methods although utilized isocratic elution with low retention times of both the analytes but they lacks stress testing on the drugs and therefore unable to separate degradation products. ICH guidelines stress to include forced degradation studies in all the developed methods including HPLC methods for pharmaceutical formulations and they must have stability indicating properties. Keeping in view the problem, we focused our attention to develop and validate a simple and precise stability indicating HPLC method for the concurrent determination of rosuvastatin and amlodipine. We are currently engaged in binary combination analysis of different classes of drugs in pharmaceutical formulations and human plasma (Qutab et al., 2007a,b; Qutab et al., 2009; Ashfaq et al., 2007; Ashfaq, Khan, Asghar, 2008; Khan et al., 2008, Khan et al., 2010; Khan et al., 2013; Khan, Jilani, Ashfaq, 2010; Sharif et al., 2010.; Razzaq et al., 2012a,b,c,d; Razzaq et al., 2013). The present work is therefore aimed to attain the optimum chromatographic conditions for the simultaneous determination of rosuvastatin and amlodipine in pharmaceutical formulations. The developed method is capable to separate both the pharmaceutical components in less than twenty minutes and therefore can be proficiently utilized in quality control analysis of both drugs and for other analytical purposes.

\section{MATERIAL AND METHODS}

\section{Chemicals and reagents}

Reference standards of both rosuvastatin calcium and amlodipine with claimed purity of $99.55 \%$ and $99.06 \%$ respectively, were kindly donated by Schazoo Zaka Laboratories (Lahore, Pakistan). The combination

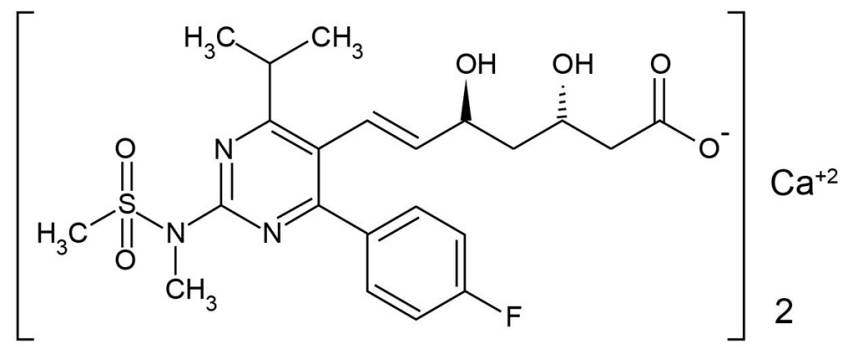

(A)

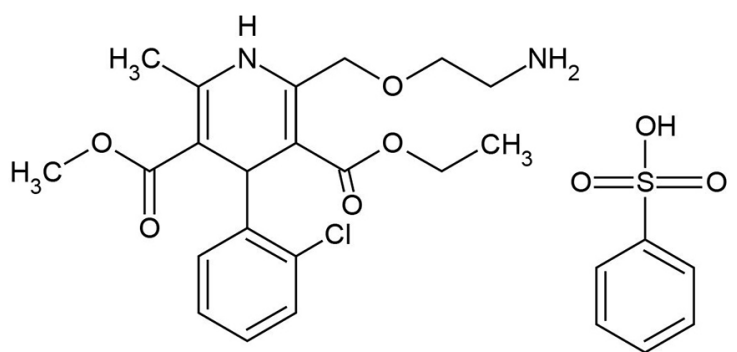

(B)

FIGURE 1 - Chemical structures of rosuvastatin calcium (A) and amlodipine besylate (B). 
drug product claimed to contain $10 \mathrm{mg}$ rosuvastatin and $5 \mathrm{mg}$ amlodipine were purchased from the local market. HPLC grade acetonitrile and analytical reagent grade other chemicals were purchased from Fluka and were used without further purification. Throughout the analysis, double distilled water was used. Nylon filters $(0.45 \mu \mathrm{m})$ for mobile phase filtration were from Millipore, USA.

\section{Equipment and chromatographic conditions}

Shimadzu LC-20A system (Shimadzu, Japan) was used for performing all the experiments including development and its subsequent validation. The system was equipped with online degasser and auto sampler. Detections of both components were performed at $240 \mathrm{~nm}$ and Class VP HPLC software was used for peak areas calculations. Reversed phase discovery C 18 column $(250 \times 4.6 \mathrm{~mm}, 5 \mu \mathrm{m}$ particle size $)$ was used at room temperature. Mobile phase was prepared by mixing acetonitrile and $0.1 \mathrm{M}$ ammonium acetate $(\mathrm{pH} 5.0)$ in the ratio of $30: 70(\mathrm{v} / \mathrm{v})$. Isocratic elution was carried out with $1.5 \mathrm{~mL} / \mathrm{min}$ as flow rate of the mobile phase.

\section{Preparation of standard solution}

The standard stock solution of rosuvastatin and amlodipine was prepared by accurately weighing $50 \mathrm{mg}$ of rosuvastatin and $25 \mathrm{mg}$ amlodipine in $50 \mathrm{ml}$ volumetric flask, sonicated with few $\mathrm{ml}$ of the mobile phase and then marked up to point with mobile phase. This provides the concentration of rosuvastatin and amlodipine equal to $1000 \mu \mathrm{g} / \mathrm{mL}$ and $500 \mu \mathrm{g} / \mathrm{mL}$, respectively. The solutions of different concentrations were then prepared by diluting the standard stock solution with mobile phase by using the dilution formulae.

\section{Preparation of sample solution}

Average weight of twenty tablets were taken and then ground manually with mortar and pestle. A weighed portion of the ground tablets, which was equal to $50 \mathrm{mg}$ rosuvastatin and $25 \mathrm{mg}$ amlodipine, was dissolved in $50 \mathrm{~mL}$ of mobile phase. The solution obtained above was then further diluted to get desired concentrations.

\section{Linearity}

To carry out the linearity, six different concentrations of rosuvastatin and amlodipine ranging from $1 \mu \mathrm{g} / \mathrm{mL}$ to $200 \mu \mathrm{g} / \mathrm{mL}(1,5,10,50,100$ and $200 \mu \mathrm{g} / \mathrm{mL})$ and $0.5 \mu \mathrm{g} / \mathrm{mL}$ to $100 \mu \mathrm{g} / \mathrm{mL}(0.5,2.5,5,25,50$ and $100 \mu \mathrm{g} / \mathrm{mL})$, respectively, were prepared and analyzed. Triplicate analysis of each solution was performed.

\section{Limit of detection (LOD) and limit of quantification (LOQ)}

For calculating LOQ and LOD of the developed method, blank solution and a solution spiked with known concentrations of each analyte in decreasing concentration were prepared and injected into HPLC system. The LOD and LOQ were calculated for both the drugs by measuring the minimum level of analytes that can be detected (Signal to noise ratio of 3:1) and quantified (Signal to noise ratio of 10:1) with accuracy and precision by the system.

\section{Accuracy}

For demonstrating accuracy, known amounts of rosuvastatin and amlodipine were added into the preanalyzed solutions. Theoretical and experimental results were then compared. The solutions corresponding to 50, 100 and $150 \%$ of the nominal analytical concentration were prepared for this purpose i.e. $50 \mu \mathrm{g} / \mathrm{mL}$ for rosuvastatin and $25 \mu \mathrm{g} / \mathrm{mL}$ for amlodipine.

\section{Precision}

For intraday precision, three set of concentrations of rosuvastatin and amlodipine were tested five times within the same day. From these replicates, percentage RSD was calculated. For inter day precision, same samples which were used for intraday precision are tested for three consecutive days. RSD was then calculated from those.

\section{Robustness}

Pre-meditate variations were carried out in the experimental conditions of the proposed method to assess the method robustness. For this, small variations were made in the operating conditions of the method like mobile phase composition, flow rate and $\mathrm{pH}$ of buffer solution. The effect of these changes on chromatographic results was then measured.

\section{Forced degradation studies}

To carry on forced degradation studies, $2 \mathrm{~mL}$ each of standard solution was taken in four different $25 \mathrm{~mL}$ volumetric flasks. All the four flasks were marked as acid, base, oxidative and thermal. $2 \mathrm{~mL}$ of $5 \mathrm{M} \mathrm{HCl}$ was added in acid flask, $2 \mathrm{~mL} 5 \mathrm{M} \mathrm{NaOH}$ in basic flask and $1 \mathrm{~mL}$ 
of $6 \%$ hydrogen peroxide in oxidative flask were added. The thermal flask was remained as such. All the flasks except oxidative flask were placed at $60^{\circ} \mathrm{C}$ for four hours. After completion of stress time, all the three flasks were cooled, and acid and base flasks were neutralized using appropriate amount of either $5 \mathrm{M} \mathrm{HCl}$ or $5 \mathrm{M} \mathrm{NaOH}$. The oxidative flask was kept at room temperature for $24 \mathrm{~h}$. All the stressed samples were then completed up to the mark and analyzed by the proposed method.

\section{RESULTS AND DISCUSSION}

The aim of the present research work was to develop a sensitive, accurate, isocratic and simple HPLC method for the separation and estimation of rosuvastatin and amlodipine along with their stress induced degradation products. Initially various mobile and stationary phases were attempted to accomplish the best separation conditions and resolution between rosuvastatin, amlodipine and their stress induced degradation products. Among all the stationary phases, C-18 stationary phase $(250 \mathrm{~mm} \times 4.6 \mathrm{~mm})$ was found best for the resolution of both the drugs. For the selection of appropriate mobile phase composition, acetonitrile was selected along with water in different proportions as the start-up mobile phase. Different proportions of these two solvents were tried but all found unsuitable as good peaks were not obtained. The poor peak shapes were expected to be due to the lesser polarity of the mobile phase. So in the next phase, polarity of the mobile phase was increased by replacing the water with ammonium acetate buffer. At $60: 40 \mathrm{v} / \mathrm{v}$ ratio of acetonitrile and ammonium acetate, better peaks for both the drugs were obtained but with certain tailing. In order to reduce tailing, $\mathrm{pH}$ of the ammonium acetate solution was varied. For this purpose, $0.1 \mathrm{M}$ ammonium acetate with $\mathrm{pH}$ equal to 3.0, 5.0 and 7.0 were tried along with acetonitrile in $40: 60 \mathrm{v} / \mathrm{v}$ ratios. Among the three buffer solution, $\mathrm{pH}$ 5.0 was proved to be the best where sharp peaks were obtained with acceptable tailing and resolution. When this mobile phase composition was applied to analyze samples, stressed through acid, base, hydrogen peroxide and heat, degradation products produced during the stress, interfered the peaks of the active product ingredients. Here both the acid and base stressed samples produced co-eluting peak of rosuvastatin with the degradation products. Increase of organic modifier results either with same results or peak of rosuvastatin with some degree of fronting. It was then decided to decrease the concentration of organic modifier so as to completely separate the degradation products from the main peaks. The percentage of organic modifier was varied from 60 to 28 percent by decrease of $2 \%$ each time. The main problem was associated with the separation of rosuvastatin from degradation product 5 (Deg 5 in chromatograms). At 72:28 v/v ratio of buffer and acetonitrile, all the degradation products were well separated from the main peaks with resolution greater than 3 between rosuvastatin and degradation product 5 . However, the total run time was greater than 30 minutes. At 68:32 buffer acetonitrile ratios, separation between the above two was not complete and merging of both the components was very clear. Finally, 70:30 buffer and acetonitrile were chosen as the mobile phase where resolution between rosuvastatin and degradation product 5 was exactly equal to 1.5 with reasonable run time of about 20 minutes. By employing the above mentioned chromatographic conditions, rosuvastatin and amlodipine were separated at retention times of 13.9 and $19.3 \mathrm{~min}$ respectively [Figure 2].

The developed method was validated using ICH prescribed validation parameters such as linearity, accuracy, precision, limit of detection and quantification, specificity, stability of solutions and robustness. These parameters were performed to check the validity of the proposed method.

To carry out the linearity, six different concentrations of rosuvastatin and amlodipine ranging from $1 \mu \mathrm{g} / \mathrm{mL}$ to $200 \mu \mathrm{g} / \mathrm{mL}(1,5,10,50,100$ and $200 \mu \mathrm{g} / \mathrm{mL})$ and $0.5 \mu \mathrm{g} / \mathrm{mL}$ to $100 \mu \mathrm{g} / \mathrm{mL}(0.5,2.5,5,25,50$ and $100 \mu \mathrm{g} / \mathrm{mL})$, respectively, were prepared and analyzed. The calibration curves were constructed between concentration on X-axis and peak area on $\mathrm{Y}$-axis. The regression equation for the rosuvastatin was $Y=21604 \mathrm{X}+56856$ with value of the regression constant or coefficient of determination equal to 0.996 . The regression equation for amlodipine was $Y=29444 X+29461$ with value of the regression constant or coefficient of determination equal to 0.994 . Results indicated very good correlation between the concentrations and their chromatographic response. The limits of detection of an analytical method is the concentration of analyte that corresponds to $\mathrm{S} / \mathrm{N}$ ratio (signal to noise ratio) of $3: 1$. For rosuvastatin and amlodipine that concentration corresponds to $0.15 \mu \mathrm{g} / \mathrm{mL}$ and $0.30 \mu \mathrm{g} / \mathrm{mL}$, respectively, where detector gives the desired response with $\mathrm{S} / \mathrm{N}$ ratio $3: 1$. The quantification limit is the lowest concentration detected accurately and generally corresponds to the detector response with $\mathrm{S} / \mathrm{N}$ ratio of 10:1 with acceptable precision. For rosuvastatin, $1 \mu \mathrm{g} / \mathrm{mL}$ and for amlodipine $0.5 \mu \mathrm{g} / \mathrm{mL}$ were the concentrations that produce the desired response with acceptable accuracy and precision. Therefore, LOD was $0.30 \mu \mathrm{g} / \mathrm{mL}$ and $0.15 \mu \mathrm{g} / \mathrm{mL}$, whereas LOQ was $0.5 \mu \mathrm{g} / \mathrm{mL}$ and $1 \mu \mathrm{g} / \mathrm{mLfor}$ rosuvastatin and amlodipine, respectively. 


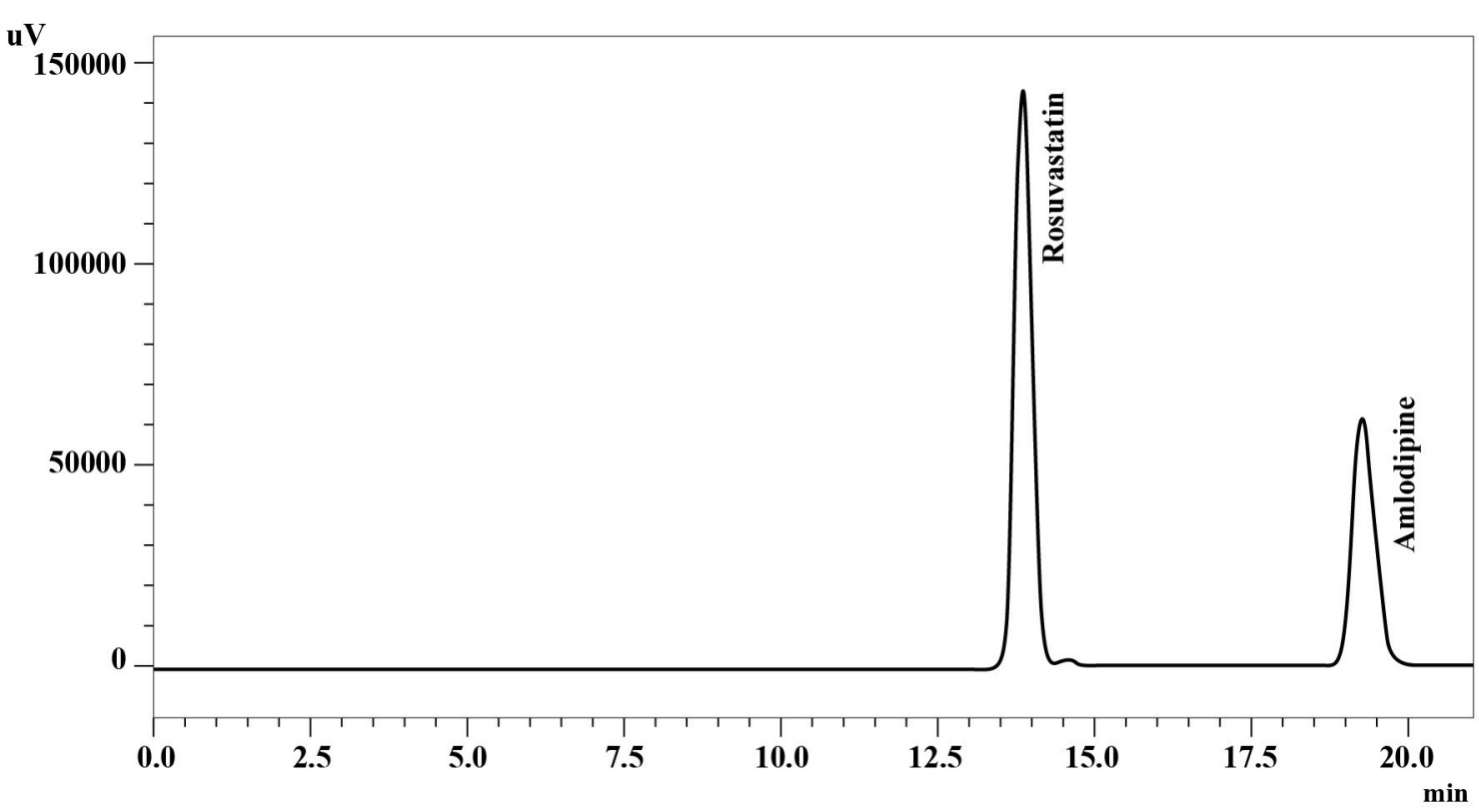

\section{IDet.A Ch1}

FIGURE - 2 Chromatogram of rosuvastatin and amlodipine reference standard.

For demonstrating accuracy, known amounts of rosuvastatin and amlodipine were added into the preanalyzed solutions. Theoretical and experimental results were then compared. The solutions corresponding to 50 , 100 and $150 \%$ of the nominal analytical concentrations were prepared for this purpose i.e. $50 \mu \mathrm{g} / \mathrm{mL}$ for rosuvastatin and $25 \mu \mathrm{g} / \mathrm{mL}$ for amlodipine. From these solutions, percentage recovery along with RSD was calculated. The results of accuracy are given in Table I.

For intraday precision, three sets of concentrations of rosuvastatin and amlodipine were tested five times within the same day. For inter day precision, same samples which were used for intraday precision were tested for three consecutive days. RSD was then calculated from both types of data which was less than $2 \%$ as shown in Table II.

TABLE I - Accuracy of the method

\begin{tabular}{lcccccc}
\hline Drug & $\mathrm{n}$ & Level $(\%)$ & $\begin{array}{c}\text { Concentration } \\
(\mu \mathrm{g} / \mathrm{mL})\end{array}$ & $\begin{array}{c}\text { Amount Recovered } \\
(\mu \mathrm{g} / \mathrm{mL})\end{array}$ & Recovery $(\%)$ & RSD (\%) \\
\hline \multirow{3}{*}{ Rosuvastatin } & 5 & 50 & 25.0 & 24.59 & 98.36 & 1.21 \\
& 5 & 100 & 50.0 & 50.02 & 100.04 & 0.99 \\
& 5 & 150 & 75.0 & 74.05 & 98.73 & 0.35 \\
\hline \multirow{3}{*}{ Amlodipine } & 5 & 50 & 12.5 & 12.39 & 99.12 & 1.39 \\
& 5 & 100 & 25.0 & 24.77 & 99.08 & 1.05 \\
& 5 & 150 & 37.5 & 37.11 & 98.96 & 0.67 \\
\hline
\end{tabular}

TABLE II - Intra-day and Inter-day precision of the method

\begin{tabular}{lccc}
\hline Compound & Concentration $(\mu \mathrm{g} / \mathrm{mL})$ & Intra-day Precision RSD $(\%)$ & Inter-day Precision RSD $(\%)$ \\
\hline \multirow{3}{*}{ Rosuvastatin } & 1.0 & 1.57 & 1.81 \\
& 10.0 & 1.18 & 1.59 \\
& 100.0 & 0.72 & 1.13 \\
\hline \multirow{3}{*}{ Amlodipine } & 0.5 & 1.49 & 1.88 \\
& 5.0 & 1.12 & 1.63 \\
& 50.0 & 0.83 & 1.23 \\
\hline
\end{tabular}


TABLE III - Robustness study of rosuvastatin

\begin{tabular}{lcccc}
\hline Conditions & Assay (\%) & $\mathrm{t}_{\mathrm{R}}(\mathrm{min})$ & Theoretical Plates & Tailing \\
\hline Acetonitrile: buffer (30:70) & 98.89 & 13.87 & 12884 & 1.12 \\
Acetonitrile: buffer (28:72) & 99.34 & 17.23 & 14114 & 1.09 \\
Acetonitrile: buffer (32:68) & 100.15 & 10.69 & 12165 & 1.15 \\
Flow rate (1.4 mL/min) & 100.53 & 14.86 & 13009 & 1.10 \\
Flow rate (1.6 mL/min) & 99.29 & 12.99 & 12264 & 1.16 \\
Buffer (pH 5.1) & 100.33 & 13.85 & 12896 & 1.13 \\
Buffer (pH 4.9) & 100.85 & 13.88 & 12784 & 1.13 \\
\hline
\end{tabular}

TABLE IV - Robustness study of amlodipine

\begin{tabular}{lcccc}
\hline Conditions & Assay (\%) & $\mathrm{t}_{\mathrm{R}}(\mathrm{min})$ & Theoretical Plates & Tailing \\
\hline Acetonitrile: buffer (30:70) & 99.78 & 19.28 & 16919 & 1.22 \\
Acetonitrile: buffer (28:72) & 100.38 & 27.56 & 18612 & 1.17 \\
Acetonitrile: buffer (32:68) & 99.08 & 15.43 & 15006 & 1.30 \\
Flow rate (1.4 mL/min) & 100.64 & 20.66 & 16812 & 1.20 \\
Flow rate (1.6 mL/min) & 98.79 & 18.08 & 17016 & 1.21 \\
Buffer (pH 5.1) & 99.25 & 19.33 & 16716 & 1.22 \\
Buffer (pH 4.9) & 99.05 & 19.30 & 16707 & 1.22 \\
\hline
\end{tabular}

Pre-meditate variations were carried out in the experimental conditions of the proposed method to assess the method robustness. For this, faint modifications were made in the operating conditions of the method like mobile phase composition, flow rate and $\mathrm{pH}$ of buffer solution. The results showed that slight variations in chromatographic conditions had negligible effect on the chromatographic parameters. The results of robustness are given in Table III and IV.

Forced degradation study was performed on both the drugs in order to judge the specificity of the described method. Different ICH prescribed stresses like acid, base, oxidative and thermal stresses were provided to both rosuvastatin and amlodipine in combined form. The chromatograms under different stress conditions are shown in [Figures 3-5]. Out of the above mentioned

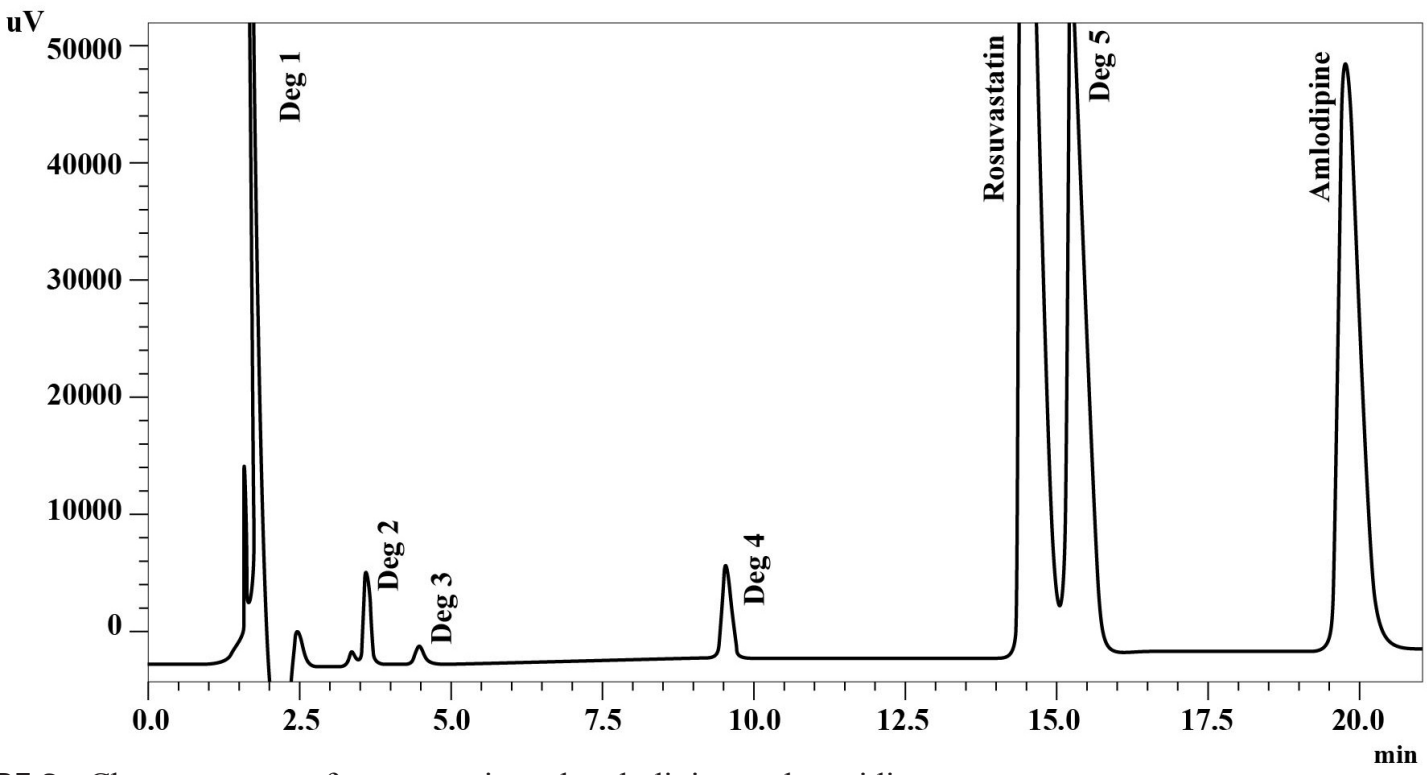

IDet.A Ch1

FIGURE 3 - Chromatogram of rosuvastatin and amlodipine under acidic stress. 


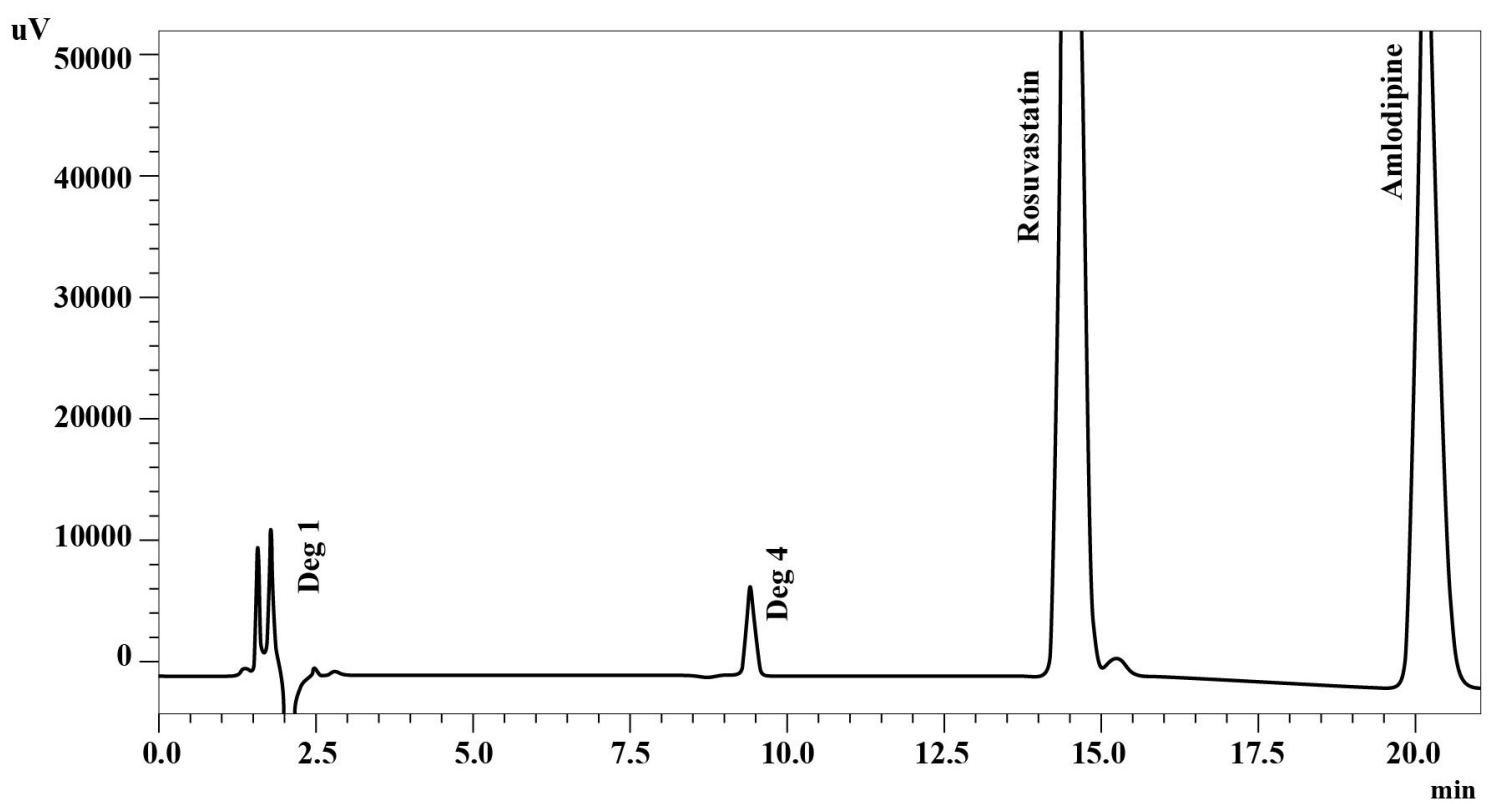

FIGURE 4 - Chromatogram of rosuvastatin and amlodipine under basic stress.

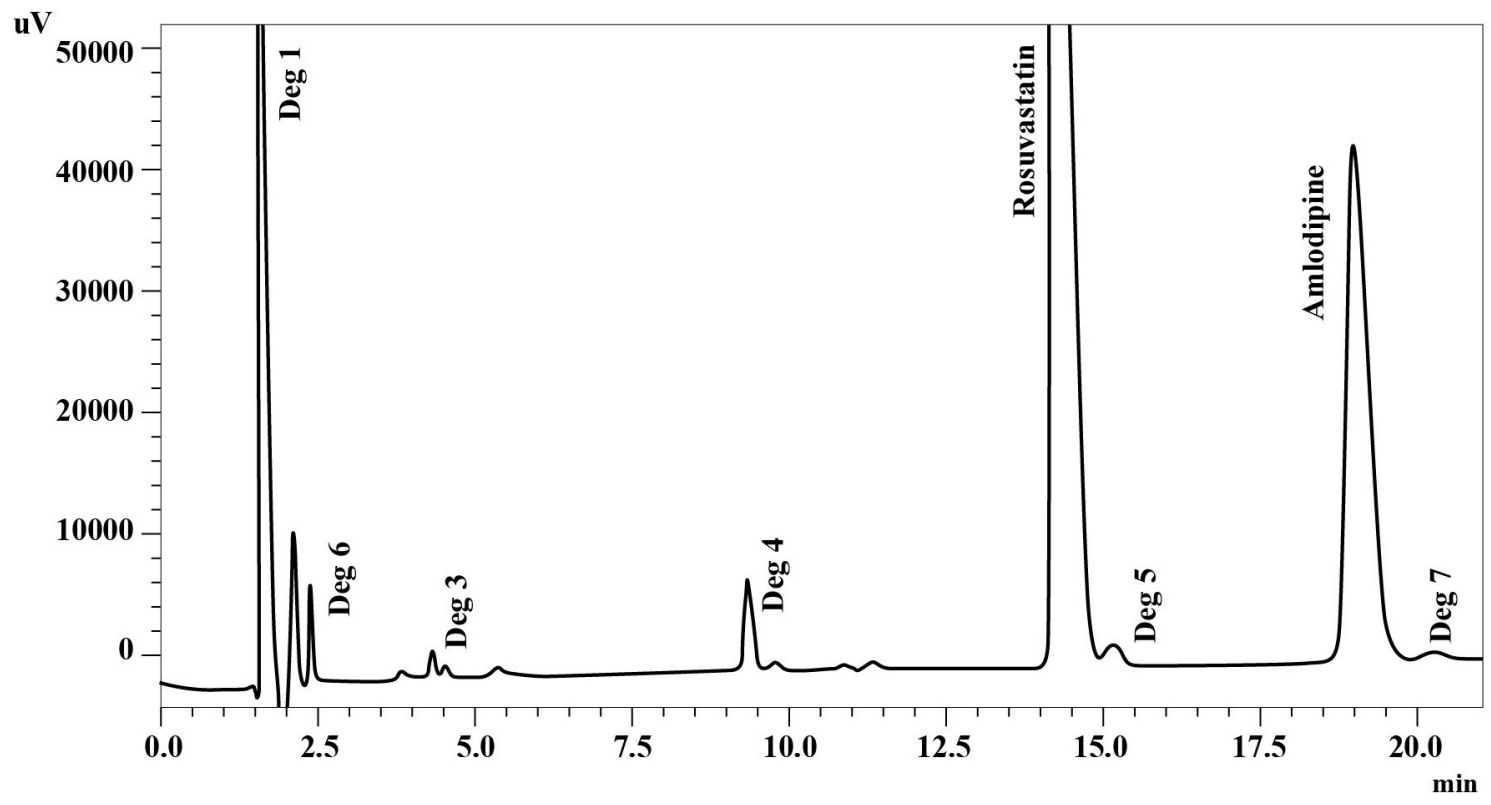

IDet.A Ch1

FIGURE 5 - Chromatogram of rosuvastatin and amlodipine under oxidative stress.

stresses, acidic, basic and oxidative stresses degrade both the drugs to some extent whereas thermal stress could not produce any degradability to them. Acidic conditions were proved to be more damaging where $40 \%$ of rosuvastatin and about $35 \%$ of the amlodipine were degraded. Under oxidative stress, the degradation of amlodipine was fast compared to rosuvastatin and about $40 \%$ of it was decomposed in contrast to only $6 \%$ of rosuvastatin. Basic stress degrades rosuvastatin to about $5 \%$ in contrast to $14 \%$ for amlodipine. Thermal stress had no effect on the degradability of both the drugs. A number of degradation products were also produced during stress testing whose chromatographic parameters are shown in Table V.

Application of the proposed method was checked by analyzing the rosuvastatin and amlodipine in commercially available pharmaceutical products. The results are provided in Table VI, which showed high percentage recoveries and low RSD (\%) values for both analytes.

To check the stability of both components, the solution of these components was placed in tight containers at room temperature for $48 \mathrm{~h}$ and their stability was checked after each 12 hours period. Results indicate 
TABLE V - Chromatographic parameters of stress induced degradation products

\begin{tabular}{lccc}
\hline Nature of Stress & Retention times $(\mathrm{min})$ & Number of theoretical plates & Tailing factors \\
\hline Acidic & $1.70,3.40,4.20,9.01,14.55$ & $3448,4895,7914,20281,13200$ & $1.58,1.18,1.23,1.08,1.25$ \\
Basic & $1.52,2.04,9.01$ & $3564,6138,20333$ & $1.58,0.75,1.09$ \\
Oxidative & $1.71,2.42,4.36,9.41,15.32$ & $3213,7503,10859,21102,13409$ & $2.45,1.38,1.07,1.11,1.25$ \\
Thermal & ----------------- & ------------------ & ------------ \\
\hline
\end{tabular}

$*_{n}=$ Average of 3 determinations

TABLE VI - Application of the method in commercial formulations

\begin{tabular}{lcccc}
\hline Ingredient & Label Value $(\mathrm{mg} /$ tablet $)$ & $\mathrm{n}$ & Found $(\mathrm{mg} /$ tablet $)$ & Recovery $(\%) \pm$ RSD $(\%)$ \\
\hline Rosuvastatin & 10.00 & 10 & 9.87 & $98.70 \pm 0.85$ \\
Amlodipine & 5.00 & 10 & 5.02 & $100.40 \pm 0.98$ \\
\hline
\end{tabular}

that their percentage recovery remained within the acceptable range and no degradation occurred during the said period.

\section{CONCLUSION}

The present work demonstrates a sensitive and reproducible HPLC method for a pharmaceutical combination comprising of an anti-hyperlipidemic agent along with an anti hypertensive drug. The method is highly selective and there was no interference caused by any kind of other particles including the degradation products produced through forced degradation study. Both the drugs and their degradation products were separated within twenty minutes. The results of accuracy, linearity, precision, LOD, LOQ and specificity indicate that method can be used not only for routine analytical analysis but also for stability studies for the separation and quantification of both rosuvastatin and amlodipine either alone or in combination with each other.

\section{REFERENCES}

ABERNETHY, D.R. The pharmacokinetic profile of amlodipine. Am. Heart. J., v.118, p.1100-1103, 1989.

ARROWSMITH, J.E.; CAMPBELL, S.F.; CROSS, P.E.; STUBBS, J.K.; BURGES, R.A.; GARDINER, D.G. Long acting dihydropyridine calcium antagonists: I-2Alkoxymethyl derivatives incorporating basic substituents. J. Med. Chem., v.29, p.1696-1702, 1986.
ASHFAQ, M.; KHAN, I.U.; QUTAB, S.S.; RAZZAQ, S.N. HPLC determination of ezetimibe and simvastatin in pharmaceutical formulations. J. Chil. Chem. Soc., v.52, p.1220-1203, 2007.

ASHFAQ, M.; KHAN, I.U.; ASGHAR, M.N. Development and validation of liquid chromatographic method for gemfibrozil and simvastatin in binary combination. J. Chil. Chem. Soc., v.53, p.1617-1619, 2008.

BANERJEE, S.K.; VASAVA, N.M. Simultaneous estimation of amlodipine and rosuvastatin in combined bulk forms by RP-HPLC using ultraviolet detection. Bull. Pharm. Res., v.3, p.29-33, 2013.

CHAUDHARI, B.G.; PATEL, N.M.; SHAH, P.B. Stability indicating RP-HPLC method for simultaneous determination of atorvastatin and amlodipine from their combination drug products. Chem. Pharm. Bull., v.55, p.241-246, 2007.

DAVIDSON, M.; MA, P.; STEIN, E.A.; GOTTO, A.M.; RAZA, A.; CHITRA, R. Comparison of effects on lowdensity lipoprotein cholesterol and high-density lipoprotein cholesterol with rosuvastatin versus atorvastatin in patients with type IIa or IIb hypercholesterolemia. Am. J. Cardiol., v.89, p.268-275, 2002.

GOMES, F.P.; GARCÍA, P.L.; ALVES, J.P.P.; SINGH, A.K.; KEDOR-HACKMANN, E.R.M.; SANTORO, M.I.R.M. Development and validation of stabilityindicating HPLC methods for quantitative determination of pravastatin, fluvastatin, atorvastatin, and rosuvastatin in pharmaceuticals. Anal. Lett., v.42, p.1784-1804, 2009. 
GUMUSTAS, M.; OZKAN, S.A. A validated stability-indicating RP-LC method for the simultaneous determination of amlodipine and perindopril in tablet dosage form and their stress degradation behavior under ICH-recommended stress conditions. J. AOAC Int., v.96, p.751-757, 2013.

KAILA, H.O.; AMBASANA, M.A.; THAKKAR, R.S.; SARAVAIA, H.T.; SHAH, A.K. A new improved RP-HPLC method for assay of rosuvastatin calcium in tablets. Indian J. Pharm. Sci., v.72, p.592-598, 2010.

KHAN, I.U.; SHARIF, S.; ASHFAQ, M.; ASGHAR, M.N. Simultaneous determination of potassium clavulanate and cefixime in synthetic mixtures by high performance liquid chromatography. J. AOAC Int., v.91, p.744-749, 2008.

KHAN, I.U.; JILLANI, S.M.S.; ASHFAQ, M. Determination of atorvastatin and gemfibrozil in human plasma by reversedphase liquid chromatography. Lat. Am. J. Pharm., v.29, p.1383-1388, 2010.

KHAN, I.U.; KAUSAR, T.; ASHFAQ, M.; SHARIF. S. Development and validation of liquid chromatographic method for the simultaneous estimation of ezetimibe and lovastatin in human plasma. J. Chil. Chem. Soc., v.55, p.461-464, 2010.

KHAN, I.U.; ASHFAQ, M.; RAZZAQ, S.N.; MARIAM, I. Simultaneous determination of piroxicam and paracetamol in pharmaceutical formulations using stability indicating HPLC method. J. Liq. Chrom. Rel. Technol., v.36, p.1437$1450,2013$.

LENNERNAS, H.; FAGER, G. Pharmacodynamics and pharmacokinetics of the HMG-CoA reductase inhibitors. Similarities and differences. Clin. Pharmacokinet., v.32, p.403-425, 1997.

MCCORMICK, A.D.; MCKILLOP, D.; BUTTERS, C.J.; MILES, G.S.; BABA, T.; TOUCHI, A. ZD4522-an HMGCoA reductase inhibitor free of metabolically mediated drug interactions: metabolic studies in human in vitro systems. J. Clin. Pharmacool., v.40, p.1055, 2000.

MEHTA, T.N.; PATEL, A.K.; KULKARNI, G.M.; SUUBBAIAH, G. Determination of rosuvastatin in the presence of its degradation products by a stability indicating LC method. J. AOAC Int., v.88, p.1142-1147, 2005.

MEREDITH, P.A.; ELLIOTT, H.L. Clinical pharmacokinetics of amlodipine. Clin. Pharmacokinet., v.22, p.22-31, 1992.
MOHAMMADI, A.; REZANOUR, N.; ANSARI DOGAHEH, M.A.; GHORBANI BIDKORBEH, F.G.; HASHEM, M.; WALKER, R.B. A stability-indicating high performance liquid chromatographic (HPLC) assay for the simultaneous determination of atorvastatin and amlodipine in commercial tablets. J. Chromatogr. B Analyt. Technol. Biomed. Life Sci., v.846, p.215-221, 2007.

MOSTAFA, N.M.; BADAWEY, A.M.; LAMIE, N.T.; ELALEEM, A.E.B.A. Stability-indicating methods for the determination of rosuvastatin calcium in the presence of its oxidative degradation products. Int. J. Pharm. Biomed. Sci., v.3, p.193-202, 2012.

NAIDU, K.R.; KALE, U.N.; SHINGARE, M.S. Stability indicating RP-HPLC method for simultaneous determination of amlodipine and benazepril hydrochloride from their combination drug product. J. Pharm. Biomed. Anal., v.39, p.147-155, 2005.

NISSEN, S.E.; NICHOLLS, S.J.; SIPAHI, I.; LIBBY, P.; RAICHLEN, J.S.; BALLANTYNE, C.M. Effect of very high-intensity statin therapy on regression of coronary atherosclerosis: the ASTEROID trial. JAMA, v.295, p.1556$1565,2006$.

OLSSON, A.G.; MCTAGGART, F.; RAZA, A. Rosuvastatin: a highly effective new $\mathrm{HMG}-\mathrm{CoA}$ reductase inhibitor. Cardiovasc. Drug Rev., v.20, p.303-328, 2002.

OLSSON, A.G.; PEARS, J.; MCKELLAR, J.; MIZAN, J.; RAZA, A. Effect of rosuvastatin on low-density lipoprotein cholesterol in patients with hypercholesterolemia. Am. J. Cardiol., v.88, p.504-508, 2001.

O` NEIL, M.J.; SMITH, A.; HECKELMAN, P.E.; BUDAVARI, S. The merck index. 14ed. City: publishing house, 2006. p.493, p.6149.

PANDYA, C.B.; CHANNABASAVARAJ, K.P.; CHUDASAMA, J.D.; MANI, T.T. Development and validation of RP-HPLC method for determination of rosuvastatin calcium in bulk and pharmaceutical dosage form. Int. J Pharm. Sci. Rev. Res., v.5, p.82-86, 2010.

PAOLETTI, R.; FAHMY, M.; MAHLA, G.; MIZAN, J.; SOUTHWORTH, H. Rosuvastatin demonstrates greater reduction of low-density lipoprotein cholesterol compared with pravastatin and simvastatin in hypercholesterolaemic patients: a randomized, double-blind study. J. Cardiovasc. Risk, v.8, p.383-390, 2001. 
QUTAB, S.S.; RAZZAQ, S.N.; ASHFAQ, M.; SHUJA, Z.A.; KHAN, I.U. Simple and sensitive LC-UV method for simultaneous analysis of hydrochlorothiazide and candesartan cilexetil in pharmaceutical formulations. Acta Chromatogr., v.19, p.119-129, 2007a.

QUTAB, S.S.; RAZZAQ, S.N.; KHAN, I.U.; ASHFAQ, M.; SHUJA. Z.A. Simultaneous determination of atorvastatin calcium and ezetimibe in pharmaceutical formulations by liquid chromatography. J. Food Drug Anal., v.15, p.139144, 2007 b.

QUTAB, S.S.; RAZZAQ, S.N.; ASHFAQ, M.; KHAN, I.U.; MUMTAZ, A.M. Simultaneous quantitation of olmesartan medoximil and amlodipine besylate in combined tablets using HPLC. J. Chil. Chem. Soc., v.54, p.234-237, 2009.

RAZZAQ, S.N.; MARIAM, I.; KHAN, I.U.; ASHFAQ, M. Development and validation of liquid chromatographic method for gatifloxacin and ketorolac tromethamine in combined dosage form. J. Liq. Chrom. Rel. Technol., v.35, p.651-661, 2012a.

RAZZAQ, S.N.; ASHFAQ, M.; KHAN, I.U.; MARIAM, I. Development and validation of liquid chromatographic method for moxifloxacin and ketorolac tromethamine in combined dosage form. Quím. Nova, v.35, p.1216-1221, 2012 b.

RAZZAQ, S.N.; ASHFAQ, M.; KHAN, I.U.; MARIAM, I. Stability indicating HPLC method for the simultaneous determination of ofloxacin and ketorolac tromethamine in pharmaceutical formulations. Anal. Methods, v.4, p.21212126, 2012c.

RAZZAQ, S.N.; ASHFAQ, M.; KHAN, I.U.; MARIAM, I. Development and validation of liquid chromatographic method for naproxen and esomeprazole in binary combination. J. Chil. Chem. Soc., v.57, p.1456-1459, 2012 d.

RAZZAQ, S.N.; ASHFAQ, M.; MARIAM, I.; KHAN, I.U.; RAZZAQ, S.S. Simultaneous RP-HPLC determination of sparfloxacin and dexamethasone in pharmaceutical formulations. Braz. J. Pharm. Sci., v.49, p.301-309, 2013.
REDDY, G.V.R.; REDDY, B.V.; HAQUE, S.W.; GAUTAM, H.D.; KUMAR, P.; KUMAR, A.P.; PARK, J.H. Development and validation of a stability-indicating UPLC method for rosuvastatin and its related impurities in pharmaceutical dosage forms. Quím. Nova, v.34, p.250-255, 2011.

SHAH, D.A.; BHATT, K.K.; MEHTA, R.S.; BALDANIA, S.L.; GANDHI, T.R. Stability indicating RP-HPLC estimation of atorvastatin calcium and amlodipine besylate in pharmaceutical formulations. Ind. J. Pharm. Sci., v.70, p.754-760, 2008.

SHARIF, S.; KHAN, I.U.; ASHFAQ, M.; IQBAL, M.S.; AHMAD. S. Development and validation of a high performance liquid chromatographic method for the simultaneous determination of potassium clavulanate and cefadroxil in synthetically prepared tablets. J. Anal. Chem., v.65, p.1029-1034, 2010.

TAJANE, D.; RAURALE, A.M.; BHARANDE, P.D.; MALI, A.N.; GADKARI, A.V.; BHOSALE, V.R. Development and validation of a RP-HPLC-PDA method for simultaneous determination of rosuvastatin calcium and amlodipine besylate in pharmaceutical dosage form. J. Chem. Pharm. Res., v.4, p.2789-2794, 2012.

TRIVEDI, H.K.; PATEL, M.C. Development and validation of a stability-indicating RP-UPLC method for determination of rosuvastatin and related substances in pharmaceutical dosage form. Sci. Pharm., v.80, p.393-406, 2012.

ZAAZAA, H.E.; ABBAS, S.S.; ESSAM, H.A.; EL-BARDICY, M.G. Validated chromatographic methods for determination of perindopril and amlodipine in pharmaceutical formulation in the presence of their degradation products. J. Chromatogr. Sci., v.51, p533-543, 2013.

Received for publication on $07^{\text {th }}$ November 2013 Accepted for publication on $07^{\text {th }}$ November 2013 